\title{
The Impact of the Sector Type on the Role of Management Information Systems for the Decision- Making Process: RNS-Sudan as Case Study
}

\author{
Mohamed Eslam Hassan \\ Jilin university, School of Management, \\ Information Science Department \\ E-mail: eslam7510@hotmail.com
}

Fengwen Zhi

Jilin university

School of Management,

Information Science Department

\author{
Ping Wang \\ Jilin university \\ School of Management, \\ Information Science Department \\ Elhadi Osman Abdalla \\ Jilin university, School of Management, \\ Management Science and Engineering Department
}

\begin{abstract}
This study purpose was to investigate the influence of the sector type on the role of management information systems in the administrative decision-making process in River Nile StateSudan. The study adopted the technique stratified random sampling to cover 200 employees in various positions in the public and same number of respondent in the private sector. Data were collected and analyzed using frequencies count, percentages and chi square test statistics. The four hypotheses generated were tested at 0.05 level of significance; the study revealed that there was no significant difference between the managers at all levels in the public and private sector in terms of the adoption of management information systems in administrative decision-making process, also there was no significant difference between the public sector and the private sector in terms of the existence of management information system will enhance the efficiency and the effectiveness of decision making process. Therefore, the study showed there was no significant difference between the public sector and the private sector in terms of that information systems help and guided the managers in policies and strategies formulations. Finally, the study revealed there was no significance difference in terms that there are some managerial and technological obstacles that limits the uses and implementations of Information Systems in the River Nile State between the public sector and the private sector.
\end{abstract}

Keywords- component; management information systems (MIS); decision making process; decision making and MIS in an organization; river nile state(RNS)/sudan

\section{INTRODUCTION}

The information technology is the most important developments in which we live these days, where it's affecting all administrative levels and in all work sites of various institutions and business organizations, and has become a real challenge facing the organization is how to work on the recruitment and use of modern technology in order to achieve efficiency and effectiveness in order to compete and staying the new environment dictated by globalization. Nowadays every aspect of management relies heavily on information to thrive and survive [1]. And management information systems are one of the most important technologies by provides several benefits to the organization: the means of effective and efficient coordination between departments; quick and reliable referencing; access to relevant data and documents; use of less labor; improvement in organizational and departmental techniques; management of day-to-day activities such as accounts, stock control, payroll, etc.; day-to-day assistance in a department and closer contact with the rest of the units. MIS provides a valuable time-saving benefit to the workforce. As the amount of raw data grow too large for employees to analyze, analysts can build a programs to enter the data and information in response to queries by management. With faster access to needed information, managers can make better decisions about procedures, future directions and make them more quickly. The main idea behind the MIS is to keep a continuous supply of information flowing to the management and afterward use the data and information gathered from MIS to make decisions [2]. We are living in a time of great change and working in an information age, managers have to gather masses of data, convert that data into information, form conclusions on this information and make decisions leading to achieve the work objectives. For an organization, information is important resource and it is essential for the survival of the organization.

\section{A. Management Information System (MIS)}

Management Information System (MIS) is generally thought of as an integrated system providing information to support operations, management and decision-making functions in an organization [1]. Management Information System (MIS) is one of the major computer information systems. Its purpose is to meet the need of public information in the organization to help decision-makers, and then MIS involves three primary resources: technology, information and people. All of these resources are important but the most important resource is people. MIS are regarded to be a subset of the overall internal controls procedures in a business, which 
cover the application of people, documents and procedures used by management accountants to solve business problems such as costing a product, service or a business-wide strategy [3]. MIS is basically concerned with the process of collecting, processing, storing and disseminating the relevant information to support the management operations in any organizations.

The information in MIS describes the firm or one of its major systems in terms of what has happened in the past, what is happening now and what is likely to happen in the future. The information is made is available in form of periodic reports, special reports and output of mathematical simulations. All managers' use the information output as they make decisions to solve the firm's problems [4]. There is no doubt that the information system helps the organization to take advantage of the most modern technology and sophisticated to keep up with the challenges and variables surrounding in order to provide the best possible service.

\section{B. Decision Making Process}

Decision-making is an essential aspect of modern management. It is a primary function of management. A manager's major job is making rational decisions. Managers take hundreds of decisions consciously and subconsciously. Decision-making is the key part of manager's activities. Decisions are important as they determine both managerial and organizational actions.

Assumed management decisions to be rational, we mean that the managers of organizations to make decisions under uncertainty: they know their alternatives; they know their results; they know the standards of their decision, and they have the ability to make the perfect choice and then implement it. According to the rational model, the decision making process can be broken down into six steps: Identifying the problem, Generating alternatives, Evaluating alternatives, Choosing an alternative, Implementing the decision, Evaluating decision effectiveness . [5].The six-step decision making process increases the likelihood that a high quality, accepted decision will result [6]. After a problem is identified, alternative solutions to the problem are generated. These are carefully evaluated, and the best alternative is chosen for implementation. The implemented alternative is then evaluated over time to assure its immediate and continued effectiveness. If difficulties arise at any stage in the process, recycling may be effected. Thus, we see that decision-making is a logical sequence of activities and moreover is the decision-making process is an iterative process, and decision-making is a recurring event, and decision makers can learn from past resolutions, and it appears clear here the role of management information systems in the process of providing the appropriate information required.

\section{Decision Making and MIS}

While the decision needs at all administrative levels of the organization to different information, where Management Information System (MIS) is basically concerned with the process of collecting, processing, storing and transmitting relevant information to support the management operations in any organizations, information systems should focus in order to meet information needs of its senior managers, middle managers and operational. Thus, the success of decisionmaking, which is the heart of administrative process, is highly

dependent partly on available information, and partly on the functions that are the components of the process.

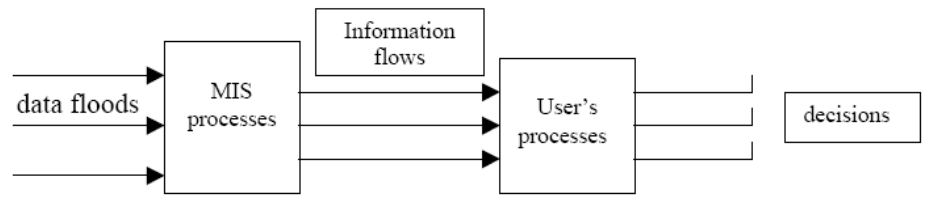

FIGURE I. MIS and decision-making process

In corroborating the important role of information in decision-making [7] advanced the notion of decision-making as a total process involving discernible and separate activities. The first of such activities is information gathering, which is followed by evaluation of alternatives and finally a choice. So involve decision-making process in the first phase to gather information, and here shows the role of management information systems in the provision of modern information and in the right time for decision-making in the organization. [8] the success of the decisions should be based on accurate information obtainable with the operation of an effective management information system. According to [9] MIS is useful in the area of decision making as it can monitor by itself disturbances in a system, determine a course of action and take action to get the system in control. It is also relevant in nonprogrammer decisions as it provides support by supplying information for the search, the analysis, the evaluation and the choice and implementation process of decision making. [10] Also maintains that MIS is useful in making decisions to solve many of the problems. [11] Stressed the need for MIS in decision making as it provides information that is needed for better decision making on the issues affecting the organization regarding human and material resources. The basic function of management information systems is providing integrated information and appropriate that can help in making the best decision. Information plays a crucial role in the decisionmaking process. Decision- making is the process of choosing what to do by considering the possible consequences of different choices [12].

\section{PURPOSE OF THE STUDY}

The purpose of this study is to find out whether there is an effect on the type of the sector on the use of management information systems in decision-making process. In other words, is there a significant difference of the influence of the sector type on the role of management information systems in the administrative decision-making process in River Nile StateSudan.

\section{MATERIAL AND METHODS}

This research adopted the descriptive analytical method, and used the questionnaire specifically designed to collect data and analyze it in order to test the study hypotheses, note that the questionnaire was presented to the professionals Field of scientific research, was the use of averages and standard deviations and percentages And extract the value of chi square, data has been entered in a computer using SPSS statistical 
software. The population of the study is a reflection of workers in some of the country's ministries (RNS / Sudan), which covers the Ministry of Agriculture, Health, Secretariat of the Government, Finance, Education, Sports and Social Affairs as a sample of the public sector and Atbara Cement Company, Alsalam Cement Company and Atbara flour mills as a sample of the private sector. Stratified random sampling technique was adopted to cover employees in various positions in the public and private sector.

\section{RESULTS AND DISCUSSION}

The results in Table (1) show that the percentage of female in the public sector is higher than the percentage of female in the private sector, which means that the private sector tends not to appoint women too much, probably due to the fact that the private sector in general is profitable sector, thus reduces the rate of recruitment of women because of circumstances holidays repeated for women, which reduces their productivity.

TABLE I. STUDY GENDER TYPE

\begin{tabular}{|c|c|c|}
\hline sector & Male & Female \\
\hline Public & $43.5 \%$ & $56.5 \%$ \\
\hline Private & $74.0 \%$ & $26.0 \%$ \\
\hline
\end{tabular}

Table (2) shows that the respondent range of ages 30 and less than 40 represents the largest proportion in the public sector and the private sector, followed by age range 20 and less than 30 in the public sector and 40 and less than 50 in the private sector.

TABLE II. STUDY SAMPLE AGE

\begin{tabular}{|c|c|c|c|c|}
\hline sector & $\begin{array}{c}\mathbf{2 0}-\text { less than } \\
\mathbf{3 0}\end{array}$ & $\begin{array}{c}\mathbf{3 0} \text { - less than } \\
\mathbf{4 0}\end{array}$ & $\begin{array}{c}\mathbf{4 0} \text { - less than } \\
\mathbf{5 0}\end{array}$ & $\begin{array}{c}\text { More than } \\
\mathbf{5 0}\end{array}$ \\
\hline Public & $28.0 \%$ & $39.5 \%$ & $24.0 \%$ & $8.5 \%$ \\
\hline Private & $23.5 \%$ & $35.0 \%$ & $28.0 \%$ & $13.5 \%$ \\
\hline
\end{tabular}

This result indicates that the private sector concentrates on the experiences in the work, while the public sector concentrates on the creation of new jobs for graduates. This reflects that the private sector's looking for profits, while the public sector mainly provides main services to the community.

As shown in table (3) that the percentage of graduates was the highest percentage in the both sector, followed by the postgraduate in the public sector and high School in the private sector, refers to the fact that the private sector does not concentrates on the appointment of postgraduate whom requires high salary which would result in reducing the profit .

TABLE III. EDUCATIONAL LEVEL

\begin{tabular}{|c|c|c|c|}
\hline sector & High School & Graduate & Postgraduate \\
\hline Public & $18.5 \%$ & $59.5 \%$ & $22.0 \%$ \\
\hline Private & $28.5 \%$ & $61.0 \%$ & $10.5 \%$ \\
\hline
\end{tabular}

The participants were asked to specify their job position the result as shown in Table (4) show that general manager in public sector constitute $2.0 \%$, while in the private sector constitute $1.5 \%$.MIS manager $4.0 \%, 3.0 \%$ in public and private sector respectively. Other department manager $22.5 \%, 16.5 \%$ in the both sector respectively .officers represents $62.5 \%$ in the public sector, $56.0 \%$ in the private sector. Employee's represents $7.5 \%$ in the public sector while represents $23.0 \%$ in the private sector.

TABLE IV. JOB DESCRIPTION

\begin{tabular}{|c|c|c|c|c|c|}
\hline sector & $\begin{array}{c}\text { General } \\
\text { Manager }\end{array}$ & $\begin{array}{c}\text { MIS } \\
\text { Manager }\end{array}$ & $\begin{array}{c}\text { Other Dept. } \\
\text { Manager }\end{array}$ & Officer & Employee \\
\hline Public & $2.0 \%$ & $4.0 \%$ & $22.5 \%$ & $62.5 \%$ & $7.5 \%$ \\
\hline Private & $1.5 \%$ & $3.0 \%$ & $16.5 \%$ & $56.0 \%$ & $23.0 \%$ \\
\hline
\end{tabular}

Table (5) confirms that the private sector seeks to achieve the highest possible profit, where the percentages from the table show that the private sector employees with work experience more than fifteen year of work experience was the predominant, while in the public sector the majority was less than five years of experience represented $35.5 \%$.

TABLE V. WORK EXPERIENCE

\begin{tabular}{|c|c|c|c|c|}
\hline sector & $\begin{array}{c}\text { Less than 5 } \\
\text { years }\end{array}$ & 5-10 years & 11-15 years & $\begin{array}{c}\text { More than } \\
\text { 15 years }\end{array}$ \\
\hline Public & $35.5 \%$ & $24.5 \%$ & $13.5 \%$ & $26.5 \%$ \\
\hline Private & $28.0 \%$ & $25.0 \%$ & $8.0 \%$ & $39.0 \%$ \\
\hline
\end{tabular}

Table (6) reveals that more than $83 \%$ of the respondents used the computer in the public sector, and $77 \%$ in the private sector, this statistic indicates that the widespread used of the computer in the two sectors, which supports the study and emphasizes that the study's sample familiarity with the information's meaning contained in the questionnaire.

TABLE VI. EMPLOYMENT OF COMPUTER IN WORK

\begin{tabular}{|c|c|c|}
\hline sector & Use the Computer & Not Use the Computer \\
\hline Public & $83.5 \%$ & $15.5 \%$ \\
\hline Private & $77.0 \%$ & $23.0 \%$ \\
\hline
\end{tabular}

A. The managers rely on Management Information Systems for decision-making

To achieve the main objective of this study, the questionnaire includes four types of questions, first: asked the represent study's sample to determine: If managers rely on management information systems for decision-making, through the provision of four questions relating to this subject. As a result, it was clear that the represent in the both sector agreed to adopt the managers on the management information systems in decision-making, statistical results as shown in table (7) indicated that the importance of MIS in decision-making, because Managers in all levels of organization hierarchy need precise and suitable data and information to make decisions that increase organizational performance. This study suggests there is no difference between the public sector and the private sector in the role of management information systems in the decision-making process in terms of the impact of the sector type. 
TABLE VII. THE MANAGERS RELY ON MANAGEMENT INFORMATION SYSTEMS FOR DECISION -MAKING.

\begin{tabular}{|l|l|l|l|l|}
\hline & \multicolumn{2}{|c|}{ Strong Agree } & \multicolumn{2}{c|}{ Agree } \\
\hline \multicolumn{1}{|c|}{ Sector type } & public & private & public & private \\
\hline $\begin{array}{l}\text { Foundation relies on information } \\
\text { produced by the information } \\
\text { system in the decision-making } \\
\text { process? }\end{array}$ & $34.5 \%$ & $29.0 \%$ & $43.0 \%$ & $51.5 \%$ \\
\hline $\begin{array}{l}\text { Corporation policies are based } \\
\text { on information provided by } \\
\text { information systems. }\end{array}$ & $21.0 \%$ & $27.0 \%$ & $55.5 \%$ & $53.5 \%$ \\
\hline $\begin{array}{l}\text { Information system helps to } \\
\text { provide alternatives in the } \\
\text { administrative decision-making } \\
\text { process. }\end{array}$ & $32.0 \%$ & $34.0 \%$ & $50.0 \%$ & $55.5 \%$ \\
\hline $\begin{array}{l}\text { In my daily work, I mainly } \\
\text { depend on the information that } \\
\text { has been generated by the } \\
\text { information system in the } \\
\text { decision-making process. }\end{array}$ & $21.0 \%$ & $23.0 \%$ & $46.0 \%$ & $54.0 \%$ \\
\hline
\end{tabular}

The study confirmed that managers rely on management information systems in the decision-making process, the results of this study confirm with [13]: The basic idea about management information system measures inputs and/or outputs, allowing managers to analyze the relationship between them, and make decisions. Also [11] stressed the need for MIS in decision making as it provides information that is needed for better decision making on the issues affecting the organization regarding human and material resources. Also [14] Management information systems give managers quick access to information. Finally, Management Information systems play the crucial role of providing a wide range of streamlined options from which decision-makers are able to make their preferred choices [15].

\section{B. MIS improves the efficiency and the effectiveness of decision making process}

Then asked the represent to determine: if the management information systems improve the efficiency and the effectiveness of decision making process, through the provision of the thirteen questions relating to this subject. As a result, as shown in table (8) below, fined the disparity percentages between strongly agree and agree.

TABLE VIII. MIS IMPROVES THE EFFICIENCY AND THE EFFECTIVENESS OF DECISION MAKING PROCESS.

\begin{tabular}{|c|c|c|c|c|}
\hline \multirow[b]{2}{*}{ Sector type } & \multicolumn{2}{|c|}{ Strong Agree } & \multicolumn{2}{|c|}{ Agree } \\
\hline & public & private & public & private \\
\hline $\begin{array}{l}\text { Information Systems provide the necessary information } \\
\text { for the decision-making process. }\end{array}$ & $33.5 \%$ & $40.0 \%$ & $49.5 \%$ & $55.0 \%$ \\
\hline $\begin{array}{l}\text { Late flow of information and access in a timely manner } \\
\text { increases the efficiency and effectiveness of } \\
\text { administrative decision. }\end{array}$ & $41.0 \%$ & $54.5 \%$ & $44.0 \%$ & $41.0 \%$ \\
\hline $\begin{array}{l}\text { Modern and concise information provided by your } \\
\text { organization's Information System increases the } \\
\text { effectiveness of the decisions taken. }\end{array}$ & $33.5 \%$ & $36.0 \%$ & $46.5 \%$ & $49.0 \%$ \\
\hline $\begin{array}{l}\text { Sharing of information electronically between the } \\
\text { different sections of the enterprise improves the decision- } \\
\text { making process. }\end{array}$ & $32.5 \%$ & $46.0 \%$ & $56.5 \%$ & $45.5 \%$ \\
\hline $\begin{array}{l}\text { The Information System in your organization provides an } \\
\text { adequate amount of information for decision-making. }\end{array}$ & $28.0 \%$ & $30.0 \%$ & $49.0 \%$ & $58.0 \%$ \\
\hline $\begin{array}{l}\text { The information that I need to make the decision are } \\
\text { provided by the information system numerically or } \\
\text { graphically or mathematically or descriptively. }\end{array}$ & $25.0 \%$ & $30.5 \%$ & $54.0 \%$ & $50.5 \%$ \\
\hline $\begin{array}{l}\text { The Information System provides integrated and } \\
\text { appropriate information to the decision-making process. }\end{array}$ & $27.5 \%$ & $30.0 \%$ & $55.0 \%$ & $50.5 \%$ \\
\hline $\begin{array}{l}\text { The Information System provides flexible information to } \\
\text { adapt and meet the different needs of beneficiaries. }\end{array}$ & $27.0 \%$ & $34.0 \%$ & $57.5 \%$ & $49.5 \%$ \\
\hline $\begin{array}{l}\text { Accurate information provided by your organization's } \\
\text { Information System increases the effectiveness of the } \\
\text { decisions taken. }\end{array}$ & $28.5 \%$ & $31.0 \%$ & $53.5 \%$ & $45.5 \%$ \\
\hline $\begin{array}{l}\text { The Information System helps enterprise to facilitate the } \\
\text { task of dealing with other public and private institutions } \\
\text { to complete the transaction as soon as possible. }\end{array}$ & $37.0 \%$ & $38.5 \%$ & $51.0 \%$ & $53.0 \%$ \\
\hline $\begin{array}{l}\text { Using electronic technologies during meetings saves time } \\
\text { and effort and facilitates the decision-making process. }\end{array}$ & $38.0 \%$ & $43.5 \%$ & $47.5 \%$ & $46.0 \%$ \\
\hline $\begin{array}{l}\text { Using the password gives a good protection of } \\
\text { information and can therefore be relied upon in the } \\
\text { decision-making process. }\end{array}$ & $40.0 \%$ & $49.5 \%$ & $47.5 \%$ & $37.5 \%$ \\
\hline $\begin{array}{l}\text { Information System helps the institution to make use of } \\
\text { the most recent and sophisticated technology to keep up } \\
\text { with the challenges and the surrounding variables in } \\
\text { order to provide the best possible service. }\end{array}$ & $39.0 \%$ & $47.5 \%$ & $50.0 \%$ & $44.5 \%$ \\
\hline
\end{tabular}


We believe that the MIS contain sufficient information for the work which increases the efficiency and effectiveness of the decision-making process and it contributes to providing historical information about the work. Reconnaissance results show agreement of the public sector and the private sector represents of that the used of the management information systems is improves the effectiveness and efficiency of the decision-making process in the organization. Also this study suggests that there is no difference between the public sector and the private sector in the improving the efficiency and the effectiveness of decision making process. These results confirm that the success of decision-making is highly dependent on available information and partly on the functions that are the components of the process for effective decisions to evolve in any organization, therefore, receiving information from and supplying information to, people within the system are a necessity.
The results of this study confirm with [16] results. Who pointed out that the role of a management information system is to convert data from internal and external sources into information that aid in making effective decisions for planning, directing and controlling the activities for which they are responsible. Also this result agrees with [17] result: MIS have improved effectiveness of decision-making of a range of different tasks. The efficiency and effectiveness of decisionmaking is corrected with improved use of MIS.

\section{Information systems help and guide the managers in policies and strategic plans}

The third part of the study contains seven questions related to the contribution of information systems in the development of policies and strategic plans, Also, according to the answers of represent table (9) shows that the limited to the highest percentages in agree, in the private and public sectors.

TABLE IX. INFORMATION SYSTEMS HELP AND GUIDE THE MANAGERS IN POLICIES AND STRATEGIC PLANS.

\begin{tabular}{|c|c|c|c|c|}
\hline \multirow[b]{2}{*}{ Sector type } & \multicolumn{2}{|c|}{ Strong Agree } & \multicolumn{2}{|c|}{ Agree } \\
\hline & public & private & public & private \\
\hline $\begin{array}{l}\text { Information System provides predictive information to help } \\
\text { decision-makers. }\end{array}$ & $33.0 \%$ & $32.5 \%$ & $54.5 \%$ & $54.5 \%$ \\
\hline $\begin{array}{l}\text { Information system helps in planning, setting goals and drawing } \\
\text { appropriate strategies for your organization. }\end{array}$ & $29.5 \%$ & $36.5 \%$ & $54.5 \%$ & $51.5 \%$ \\
\hline $\begin{array}{l}\text { Information System helps the organization in the functional } \\
\text { activities related to the job and its objectives. }\end{array}$ & $34.5 \%$ & $33.5 \%$ & $53.5 \%$ & $56.0 \%$ \\
\hline $\begin{array}{l}\text { Information Management System facilitates the process of } \\
\text { communication and follow-up and auditing for various activities. }\end{array}$ & $36.0 \%$ & $34.5 \%$ & $53.5 \%$ & $57.5 \%$ \\
\hline $\begin{array}{l}\text { Information Management System establishes a clear vision for the } \\
\text { financial and administrative operations of the functional activities. }\end{array}$ & $32.0 \%$ & $34.0 \%$ & $51.5 \%$ & $55.0 \%$ \\
\hline $\begin{array}{l}\text { Information Systems can be used to give updated information that } \\
\text { may be relied upon to make future decisions. }\end{array}$ & $33.5 \%$ & $43.0 \%$ & $52.0 \%$ & $50.5 \%$ \\
\hline $\begin{array}{l}\text { Availability of Information Systems technologies contributes to } \\
\text { the decision-making process at anytime and anywhere. }\end{array}$ & $33.0 \%$ & $38.5 \%$ & $48.0 \%$ & $50.5 \%$ \\
\hline
\end{tabular}

Again there is no difference between the public sector and the private sector, with regard to role of the MIS for help and guide the managers in policies and strategic plans, this results confirm that The role of information systems in the development of administrative policies and strategic plans in any organization.

The results of this study confirm with [18] results. Their study discovers that adequate IT investment and acceptance will improve employee's capacity and employees' knowledge can better predict organizational outcomes. MIS also aimed to assist managers and operating personnel, to produce timely and accurate information not only to decide present and future operations, but also to pinpoint potential problems that need to be rectified [1].Finally, MIS provides accurate and timely information necessary to facilitate the decision-making process and enable the organizations planning, control, and operational functions to be carried out effectively [19]. Despite the positives associated with the role of MIS in decision making process, there are a few challenges that are believed to limit the efficacy of MIS [20].

\section{The obstacles limit the use and implementation of MIS in the River Nile State}

Respondents were asked to determine the obstacles that limit the role of information systems in management decisionmaking through nine questions shown in the table (10).It is clear that the sample of the study agree that there are constraints limiting the development of MIS in the both sector. 
TABLE $X$. The OBSTACLES Limit the USE AND IMPLEMENTATION OF MIS IN THE River NiLE STATE

\begin{tabular}{|c|c|c|c|c|}
\hline \multirow[b]{2}{*}{ Sector type } & \multicolumn{2}{|c|}{ Strong Agree } & \multicolumn{2}{|c|}{ Agree } \\
\hline & public & private & public & private \\
\hline $\begin{array}{l}\text { Lack of Hardware and other equipment required limits } \\
\text { the effectiveness of the information system. }\end{array}$ & $46.0 \%$ & $54.5 \%$ & $42.5 \%$ & $37.0 \%$ \\
\hline $\begin{array}{l}\text { Lack of appropriate software and applications reduces } \\
\text { the efficiency and effectiveness of the Information } \\
\text { System. }\end{array}$ & $47.5 \%$ & $50.0 \%$ & $43.5 \%$ & $42.5 \%$ \\
\hline $\begin{array}{l}\text { Lack of qualified personnel who can deal with the } \\
\text { systems hinders the development of the Information } \\
\text { System. }\end{array}$ & $50.0 \%$ & $57.5 \%$ & $36.5 \%$ & $34.0 \%$ \\
\hline $\begin{array}{l}\text { Problems of maintenance for devices and auditing of } \\
\text { applications in the event of malfunction. }\end{array}$ & $38.5 \%$ & $45.5 \%$ & $43.0 \%$ & $36.5 \%$ \\
\hline $\begin{array}{l}\text { Lack of dealing with local area networks and the } \\
\text { World Wide Web "internet" reduces the efficiency of } \\
\text { the information system. }\end{array}$ & $35.5 \%$ & $45.0 \%$ & $48.0 \%$ & $43.0 \%$ \\
\hline $\begin{array}{l}\text { Lack of information systems reduces satisfaction and } \\
\text { job stability. }\end{array}$ & $32.5 \%$ & $38.5 \%$ & $49.5 \%$ & $46.0 \%$ \\
\hline Lack of information system increases the routine work. & $34.5 \%$ & $48.0 \%$ & $42.5 \%$ & $37.5 \%$ \\
\hline $\begin{array}{l}\text { Lack of information system creates duplication of } \\
\text { work. }\end{array}$ & $30.0 \%$ & $40.5 \%$ & $43.5 \%$ & $42.5 \%$ \\
\hline $\begin{array}{l}\text { Decision-making process in the public sector is random } \\
\text { and does not depend on the availability of accurate } \\
\text { information produced by from the information systems }\end{array}$ & $40.5 \%$ & $44.5 \%$ & $37.0 \%$ & $35.5 \%$ \\
\hline
\end{tabular}

It is clear from the results that a large proportion of respondents agree that the lack of qualified staff who can deal with the information systems as the most important obstacle, Strong agree answer was the percentage represented the highest in the public sector and the private sector amounted to50.0\% and $57.5 \%$ respectively. This result confirms that there is no difference between the public sector and the private sector with regard to the role of management information systems in the decision-making process, in other words, no effect for the type of sector on the role of information systems in the administrative decision-making process within the institutions, this may be due to the fact that third world countries do not have a long history of science and information technology, there is no formal policies or standards or informal or still in the early stages and the newly formed and this which was confirmed by the results of this study.

This study supports previous studies confirm that a group of restrictions limiting the use of management information systems and reduce the efficiency and effectiveness of management information systems to perform their role. [21] Their study pointed out that several obstacles facing the development of MIS in the RNS. Also agreed with [22] who claimed users few knowledge of computers and information systems and analysts have few knowledge of the organization's affairs. This results because designed system do not meet real needs of users.

\section{HYPOTHESIS TEST}

The first hypothesis: There is no significant difference between the managers at all levels in the public and private sector in terms of the adoption of management information systems in administrative decision-making process:

The result obtained from the analysis shows that the null hypothesis is not rejected. This means that there is no significant difference in terms of the adoption of management information systems in administrative decision-making.

The second hypothesis: There is a significant difference between the public and the private sector in terms of that the existence of management information systems will enhance the efficiency and the effectiveness of decision making process:

The result obtained from the analysis shows that the null hypothesis is not rejected at 0.05 level of significance. That means there is no significant difference between the public sector and the private sector in terms of that the existence management information system will enhance the efficiency and the effectiveness of decision making process.

Third hypothesis: There is a difference between the public sector and the private sector in terms of that the information system helps and guide the managers in policies and strategies plan:

The result obtained from the analysis shows that the null hypothesis is not rejected at 0.05 level of significance. That means there is no significant difference between the public sector and the private sector in terms of that information systems help and guide the managers in policies and strategies plans.

Fourth hypothesis: There is difference in terms that there are some management and technological obstacles that limits the uses and implementations of Information Systems in the River Nile State between the public sector and the private sector:

The result of the analysis reveals that the null hypothesis is not rejected at 0.05 level of significance. This means that there is no significant difference between the public sector and the private sector in terms that there are some management and technological obstacles that limits the uses and implementations of Information Systems in the River Nile State. 


\section{CONCLUSION AND RECOMMENDATIONS}

According to the previous studies and literatures in the MIS field we can stated that information systems definitions focus on its role in enhancing and improving the decision-making operation by providing accurate and timely information required for the decision. Thus, the results of this study boosted the same strong relationship between information systems and the decision-making process.

From the analysis of the results, the study showed that, there was no a significant difference of the influence of the sector type on the role of management information systems in the administrative decision-making process in River Nile StateSudan. Moreover, the study revealed the following points:

- Managers in all levels of organization hierarchy need precise and suitable data and information to make decisions.

- The employment of management information systems improves the efficiency and effectiveness of the decision-making process in the organization. Also Information Systems can be used to obtain updated information that could rely upon to make the future decisions.

- Individuals of the study sample agree that there are many obstacles facing the development of management information systems in the RNS. Where the lack of qualified personnel who can deal with the systems ranked the highest hinders of the development of the management information system.

Researchers recommend the state government should adopt a clear policies and specific criteria to promote and develop the management information systems in public and private institutions. Moreover, the government should facilitate and support the training programs for workers. In addition they should strive to eliminate the obstacles that limit the development of management information systems in the River Nile State. We also recommend the support of the scientific research in this area to reach the best results.

\section{REFERENCES}

[1] Ajayi, I. A. and Omirin, Fadekemi F ,The use of management information systems (MIS) in decision making in the South-West Nigerian Universities. Educational Research and Review Vol. 2 (5), 2007,pp. 109-116.

[2] Philip G , Is strategic planning for operational efficiency, Information System Management, 24(3), 2007,pp.247-264.

[3] Lucey, T.,Management Information Systems, Cengage Learning EMEA; 9th ed., London. 2004.

[4] Raymond, McLeod, Jr. Raymond, Information Systems. New York, Macmillan Publishing Company,1990.

[5] Schoenfeld, A. H.,How we think: A theory of goal-oriented decision making and its educational applications, 2011, New York, NY: Routledge.

[6] Certo, S, C., Modern Management, diversity, quality, ethics and the global environment, 7th Ed, NewJersey, Prentice-Hall Inc, 1997.

[7] Sisodia RH., Development of Information Systems for Education. Englewood Cliffs, New Jersey: Prentice Hall, 1992.

[8] Adesina A., Decision-Making in Educational Administration, In A.Adeniran and E. O. Fagbamiye (eds.) Educational Administration.Ibadan University Press, 1988.
[9] Obi, Emenike., Educational Management: Theory and Practice. Enugu: JAMOE Nigeria Enterprises, 2003.

[10] Fabunmi M., "Management Information Systems in Education" in Babalola JB (ed.). Basic Text in Educational Planning. Ibadan: Department of Educational Management, University of Ibadan, Ibadan, 2003.

[11] Adebayo FA., Management Information System for Managers, AdoEkiti: Green Line Publishers, 2007.

[12] Beyth, fischoff, Jacobs and furby, Teaching Decision Making to Adolescents (J. Baron \& R. Brown (Eds.)), 1991,pp.19-60.

[13] Clarke S., Information Systems Strategic Management - An Integrated Approach,Second ed., New York: Routledge (Taylor \& Francis Group), 2007.

[14] Rhodes, J. (2010), The Role of Management Information Systems in Decision Making, eHow, Retrieved November 2013 from http://www.ehow.com/facts_7147006_role-informationsystems.

[15] Vittal A \& Shivraj K., Role of IT and KM in improving project management performance, VINE, 38 (3), 2008,pp. 357 - 369.

[16] Asefeh A;Ali S and Adeleh AZ., The Role of Management Information System (MIS) and Decision Support System (DSS) for Manager's Decision Making Process, International Journal of Business and Management, 6(7), 2011,pp.164-173.

[17] Saleh A., Management Information Systems Role in Decision-Making During Crises, Journal of Computer Science, 6(11), 2010,pp.1230-1234.

[18] Kuoa, Y.K. and K.D. Ye, How employees' perception of information technology application and their knowledge management capacity influence organizational performance, Behav.Inform. Technol., 29, 2010,pp. 287-303.

[19] Predrag R, Tanja S \& Ivana M, Management Information System and Decision Making Process in Enterprise, 2013.

[20] Nowduri. Srinivas, Management information systems and business decision making: review, analysis, and recommendations, Journal of Management and Marketing Research, Vol. 7, 2011,pp.1-8.

[21] Elhadi.Osman Abdalla; Li Quanxiu and Mohamed. Eslam Hassan , Public Sector Employees' View(s) of Obstacles Facing the Development of Management Information Systems in the River Nile State-Sudan, African Journal of Business Management, Vol. 7(24), 2013,pp.23752380.

[22] Arash H., Afshin A.k., Qmars J., Hamed A., The Role of Management information Systems (MIS) in Decision-Making and Problems of its Implementation, Universal Journal of Management and Social Sciences, Vol. 3, No.3, 2013,pp.78-89. 